\title{
ECOlogy \\ Frugivorous butterflies (Lepidoptera: Nymphalidae) as a habitat quality indicator in Cerrado urban fragment
}

\author{
leza Aparecida Teles Porath \& Rodrigo Aranda
}

Universidade Federal de Rondonópolis, MT, Brazil.

\author{
EntomoBrasilis 13: e904 (2020)
}

\begin{abstract}
Edited by:
William Costa Rodrigues

Article History:

Received: $10 . i v .2020$

Accepted: 20.v.2020

Published: 01.vii.2020

$\bowtie$ Corresponding author:

Rodrigo Aranda

७ rodrigoaranda.biologo@gmail.com

Funding agencies:

\& Without funding declared

Abstract: Environmental monitoring programs use recurrently insects to assess the quality of habitats, mainly frugivorous butterflies. These have ample availability of information, easy and lowcost method, in addition to responding easily to environmental changes, making an efficient tool in environmental diagnosis. The objective of this work was inventory the frugivorous butterflies in an urban Cerrado fragment belonging to the Universidade Federal de Rondonópolis, state of Mato Grosso, and verify the efficient as biological indicator of environmental quality. We hypothesize differences in species richness, abundance and composition between edge and center of fragment. The sampling was carried out between February and May 2019, using 10 Van Someren-Rydon traps, with six has distributed at the edges and four in the center of the fragment. The collections have taken once a week lasting three days at each event. A total of 105 individuals belonging to nine species of Nymphalidae were captured, respectively, as subfamilies: Biblidinae (71), Satyrinae (31) and Charaxinae (03). There was no significant difference between species richness, abundance and composition in the edge area and in the center. The predominance of taxa such as Hamadryas feronia Hübner, Hamadryas februa Linnaeus and Paryththimades phronius Godart evidences that fragment is in regeneration process, once the species are characteristics of regenerating environments. Therefore, the present work collaborates and demonstrates the efficiency of the use of frugivorous butterflies as indicators of habitat quality and the contribution for implantation and monitorng of protected areas, serving as parameters for future analyzes of the quality of the studied area.
\end{abstract}

Keywords: Conservation; Edge effect; Inventory.

$\triangle$ nthropic changes in the landscape and urbanization process have led to the destruction, fragmentation and isolation of natural habitats, damaging biodiversity, and thus increasing the importance of the remaining areas as refuge for fauna and flora (FAHRIG 2003; SILVA et al. 2007). Habitat fragmentation is a phenomenon where a large and continuous area of a specific habitat is reduced by two or more small areas. These new smaller areas, separated from each other by different environments from the original, can become isolated. Notable features that differentiate fragmented and natural habitats are, in addition to the decrease in habitat area, a considerable increase in the edge area (FAHRIG 2003). Due to the consequences caused by the urbanization process, local and regional inventories becomes an important tool for environmental studies, providing information on taxonomic, ecological and genetic diversity (FAHRIG 2003). With this, it is possible to carry out a general assessment of biodiversity in order to support management decisions and mitigation actions for the conservation of natural areas.

The Lepidoptera constitutes the second largest order of invertebrates in number of species, with approximately 180,000 species, $12 \%$ of which are butterflies (HEPPNER 1991; Hogue 1993; Brown Jr \& Freitas 1999; Capinera 2008). In Brazil, more than 5,000 butterflies are described (Brown 1996). The high diversity of species added to the ease of capture and extensive taxonomic knowledge are attributes that make frugivorous butterflies' good models for ecological studies (DeVries et al. 1997; DeVRies \& Walla 2001; Hamer et al. 2005;
Uehara-Prado et al. 2007; Ribeiro et al. 2012). Certain groups of insects, such as butterflies, are important in environmental monitoring. The change in species composition that responds to environmental disturbances, the different degrees of responses to landscape fragmentation is fundamental for the definition and monitoring of the conservation of small areas and fragmented habitats or with a long history of anthropic influence (DeVries 1987; Freitas et al. 2003).

Most of butterflies are diurnal, being represented by the majority of them in five families: Hesperiidae, Papilionidae, Pieridae, Lycaenidae and Nymphalidae (Brown JR \& FreItAS 2002). According to the eating habits of adults, butterflies are divided into nectarivores, which feed on nectar, and frugivores, which feed on fermented fruits, excrement, exudates of plants and decomposing animals (Dessur \& Morals 2007). The members of Nymphalidae are distributed in 14 subfamilies, with the subfamilies Satyrinae, Charaxinae, Biblidinae, and Nymphalinae being commonly sampled, which feed on fermented fruits and exudates of decomposing vegetables and animals (CAPINERA 2008). Thus, the richness of these insect species and the abundance of individuals are able to provide relevant information for the elaboration of conservation strategies for an area. Therefore, the presence or absence of certain species in a specific area may indicate the natural stability of the environment or changes in habitat that compromise environmental quality (New et al. 1995; Brown JR \& Freitas 1999; Uehara-Prado et al. 2004; Dessuy \& MORAIS 2007). 
The Brazilian Cerrado contributes about $5 \%$ of the diversity of fauna and flora worldwide and about 1/3 of the Brazilian biota (Alho \& MARTINS 1995). For this reason, it is considered an important hotsposts due to its function of richness at the endemic level and degree of threat for the species. Therefore, when conducting the study on the presence of frugivorous butterflies, it is possible to obtain information on the quality of the habitat to consequently contribute to the elaboration of mitigation measures. Thus, the objective of this work was inventory frugivorous butterflies using them as environmental indicator in an urban fragment of the Brazilian Cerrado. In addition, the hypotheses for comparing species richness, abundance of individuals and community composition between the edge area and the central region of the fragment were tested, we expecting that there will be a difference between the two regions of the study area of the metrics performed by checking the fragment quality for conservation implications.

\section{MATERIAL AND METHODS}

Study area. The study area is located at the Universidade Federal de Rondonópolis, Rondonópolis, MT (16 $26^{\circ} 23.5^{\prime}$ 'S; 54' 36' 35.8' 'W). The municipality has an urban area with approximately 232,500 inhabitants (IBGE 2018). The study site is a fragment with influence of anthropic actions, since in the south of the state of Mato Grosso due to the favorable relief to agricultural practice and an accelerated agriculture and livestock expansion. Consequently, the remaining vegetation is fragmented and isolated, being currently, representative of the regional native biodiversity characterized by several typical Cerrado formations (FELFILI \& SILVA JúNIOR 2001).

The region's predominant climate corresponds to the hot and sub-humid tropical type and its vegetation belongs to the Cerrado domain (SetTe 1996), with two climatic patterns: the dry season (May to September) and the rainy season (October to April). The average rainfall index in Rondonópolis is $1,500 \mathrm{~mm} /$ year with the concentration of rainfall in the summer (SETTE \& TARIFA 2001). The campus covers approximately 60 ha, part of which is urbanized and paved by university buildings. The sampled points are located in an area of native vegetation of the Cerrado with 17.35 ha. The vegetation is classified as Cerrado sensu stricto located on a red-yellow latosol. It is an area in a process of natural regeneration since 1980, the result of a cattle farm donation for university implantation which was surrounded for the installation of the campus, and which is currently decreasing due to new buildings in this area (DE CAMPOs et al. 2018).

Sampling. Sampling was carried out from February to May 2019 (SISBIO Authorization 61938-1) during the wet season, as it is known that the richness and abundance of frugivorous butterflies tends to increase in the wet season due to the greater availability of food resources (DEVRIES et al. 1997). The traps were arranged in two distinct areas in the fragment: central region and edge area (Figure 1). Distances from the internal points of approximately $120 \mathrm{~m}$ between each were considered. The distances between the internal points and the edge region were around $150 \mathrm{~m}$. Thus, we believe that the distance established between the central region and the edge region is sufficient to ensure that if there is a difference in the composition of the community in relation to the preference for the use of the specific habitat, individuals would not move between regions. We consider the approximate values found by BOSSART \& OPUNI-FRIMPONG (2009) in the identification of the edge effect for the butterfly community and the values of approximate distance of 150$200 \mathrm{~m}$ and to guarantee independence from the traps, considering areas of Atlantic forest (Freitas et al. 2014).

We use Van Someren-Rydon attractive traps for frugivorous butterflies, which consisted of $90 \mathrm{~cm}$ high thin-screen cylinders, closed at the top end, in which at the top there is a metal frame, and at the bottom a $3 \mathrm{~cm}$ opening for the entrance of the butterflies (DEVRIES 1987). In this opening, a plastic dish with fermented fruit baits (bananas and sugar) which were prepared $48 \mathrm{~h}$ before the start of sampling. This fermentation process is responsible for attracting frugivorous lepidopteran into the trap through the odor (FreItAs et al. 2014). The trap remained suspended from the ground, hanging from the low branches of the trees with the help of a rope. Along the study area, 10 traps were used, of which 6 were located on the edge of the fragment, and the other four were located inside it (Figure 1).

Thus, sampling was carried out weekly, with an interval of three days (72 h) with the traps open to capture the

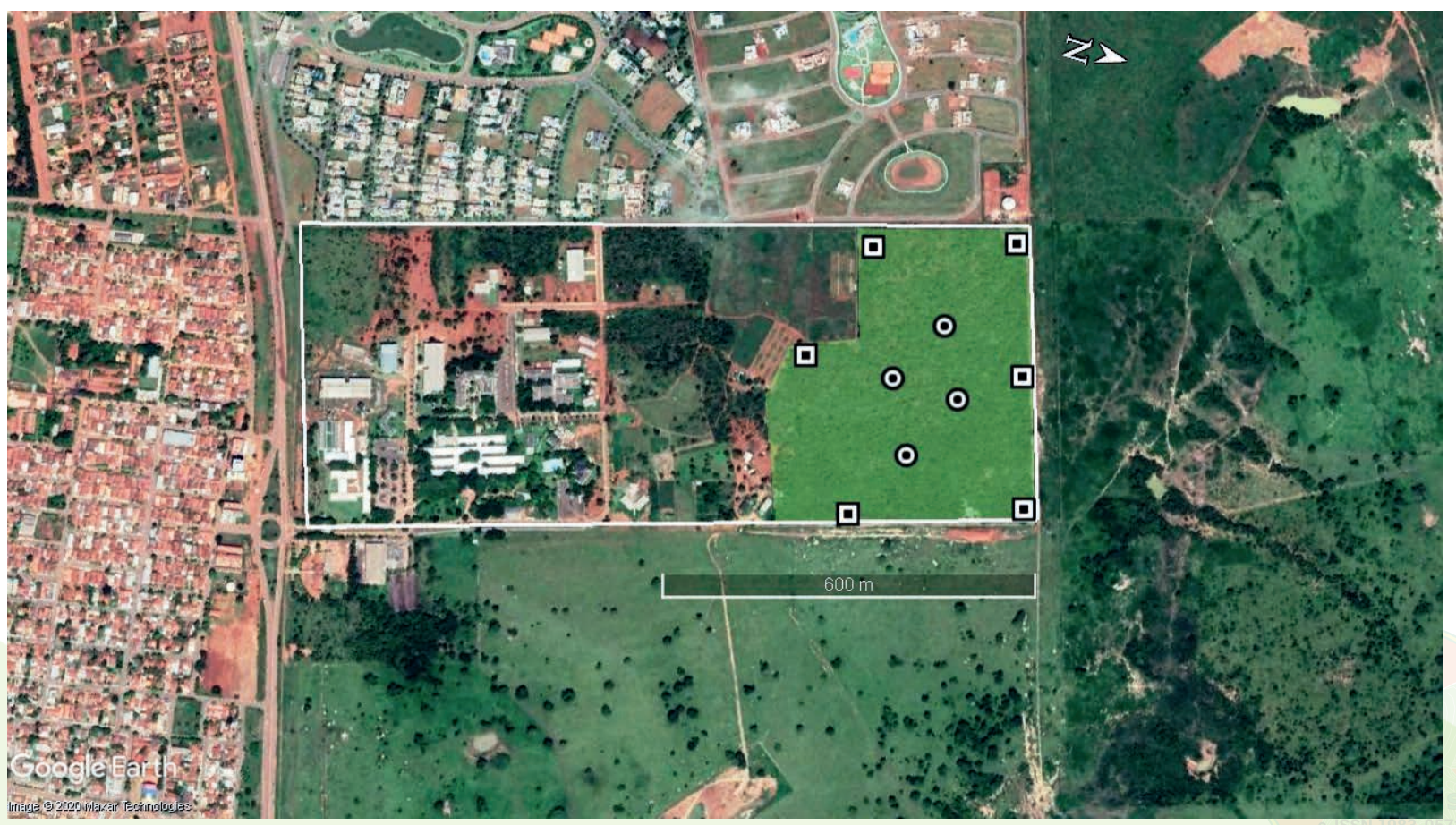

Figure 1. Van Someren-Rydon Traps distribution in the reserve area of the Universidade Federal de Rondonópolis, MT. Squares correspond to the points of edge and circles in the central region. Source: Google Earth ${ }^{\circledR} 2020$. 
specimens over 20 weeks, totaling 14,400 h/trap. The captured specimens were placed in entomological envelopes enumerated according to the collected trap and location, taken to the entomology laboratory at UFR for the material classification process, assembly on an entomological pin and subsequent identification. The identification was carried out through the butterfly monitoring and biodiversity catalog for the Cerrado (SAntos et al. 2014).

Data analysis. The data were analyzed through the description of the community, using the species richness and abundance. To compare these parameters between the center and the fragment's edge, the Mann-Whitney test was used; to compare the composition of the community the Nonparametric Multivariate Analysis test (NPMANOVA) was used; and Non-parametric Multidimensional Scaling (NMDS) for data visualization. The similarity index (SIMPER) was used to define the species responsible for the similarity percentage of the community of the captured frugivorous butterflies, in order to observe which species were more important in the different study areas. For all tests, p 0.05 was assigned, and performed using the Past ${ }^{\circledR}$ program.

\section{RESULTS AND DISCUSSION}

A total of 105 individuals were registered, distributed in nine species belonging to the three subfamilies of Nymphalidae: Biblidinae with 71 individuals, Satyrinae with 31 and Charaxinae with 3 individuals (Table 1). The sampling effort indicates a low rate of capture of individuals, with 0.007 individuals per hour of collection. The study showed low species richness when compared to other studies carried out in the Cerrado in larger and preserved areas. Sousa et al. (2019) collected 204 individuals distributed in 40 species in the Serra Azul State Park in the east of the state of Mato Grosso, an area with several Cerrado formations with 11,000 ha. JUNIOR et al. (2015) captured 3,459 individuals from 62 species of Nymphalidae at Fazenda Água Limpa (FAL) and at Roncador Ecological Reserve (RECOR) in an area of 1,350 ha located in the Distrito Federal.

Low richness was to be expected since, the closer to dense urban area, the smaller the number of species found in forest fragments, due to the disappearance of species sensitive to urbanization (SANTOS 2016). However, when compared to works carried out on urbanized fragments such as those recorded by SiLva et al. (2012) studying an urban area in Belo Horizonte where he recorded 45 species, ForTunADo \& RuszczYK (1997) studying urban and extra urban areas in Uberlândia where they recorded 36 species and BogIANI et al. (2012) where they found 28 species of Nymphalidae in approximately 60 ha in an urban Cerrado fragment in Campo Grande, MS, we see that the nine species found really reflect aspects of a small fragment inserted in the urban scene of a medium-sized city in the Cerrado region.

Comparing the regions of the edge and central area, we found that there is no significant difference between them in relation to species richness $(U=40, p=0.47)$ and abundance of individuals $(U=41.5, p=0.54$ ) (Figure $2 \mathrm{~A}$ and $2 \mathrm{~B})$, the same occurs with the composition, which is similar (NPMANOVA F $=1.71 ; p=0.1 ;$ NMDS, Stress $=0.61$ ) (Figure $3)$, with the same species inhabit the the edge are also found at interior of the fragment. The SIMPER test showed and reinforced the similarity of $77 \%$ of the sampled composition between the different points of the center and the edge of the fragment represented by similar taxa Hamadryas feronia, Linnaeus, Hamadryas februa, Huebner and Paryphthimoides phronius, Godartthat are responsible for more than 57\% similarity (Table 2). Comparing the communities at the edge and center of the fragment separately, it is clear that there is a great similarity between them with regard to composition, richness and abundance of species. These results suggest a homogeneous fauna, which may be the result of an extreme degree of environmental disturbance (McKInNEY \& LockWOOD 1999). The absence of difference between the edge and the center can be justified by the high level of alteration and the very small size of the fragment, since its size directly influences the ecological processes, due to the changes induced by the formation of the edge, that is, small fragments have a higher proportion of altered environment, due to the extension of the edge to the interior (ShAHABUdDIN \& TeRBORGH 1996; Shahabuddin \& Ponte 2005; Feiden et al. 2008; Schmidt et al. 2012).

It is notable that the presence and abundance of certain species such as $H$. feronia, $H$. februa e $P$. phronius, known as indicators of impacted environments (SiLva et al. 2007 BRown 1992), it shows that the anthropized urban fragment, resulting mainly from agricultural activities, is still a regenerating environment. This habitat is not yet complex, that is, a large edge, since these species preferentially inhabit the edge of forests, open environments and with the presence of clearings, where the food resource, probably in its larval stage, is more abundant in vines (Euphorbiaceae) in case of $H$. feronia and $H$. februa and monocotyledons in the case of butterflies of the subfamily Satyrinae, typical of open-field habitats, resulting in the high abundance of individuals of these species in this environment (Gomes FILHO 2003). This demonstrates that the anthropic disturbance in the fragment favored organisms more tolerant to the sun and desiccation, typical of these environments. In addition to the majority of species, including the most abundant of Biblidinae as Hamadryas spp., have caterpillars that feed on plants typical of early stages of succession, for using during their development host plants present in early stages of regeneration (SILVA et al. 2007). It is known that some individuals of the Nymphalidae family are common in edges

Table 1. Identification of frugivorous butterflies and the number of individuals caught in the center and edge of the urban fragment located at the Universidade Federal de Rondonópolis, MT in the May 2019 period.

\begin{tabular}{llccc}
\hline Subfamily & Species & Edge & Center & Total \\
\hline Biblidinae & Callicore sorana Godart & 10 & 0 & 10 \\
& Hamadryas februa Hübner & 5 & 12 & 17 \\
& Hamadryas feronia Linnaeus & 10 & 15 & 25 \\
& Nica flavilla Godart & 1 & 4 & 5 \\
\multirow{2}{*}{ Charaxinae } & Temenis laothoe Cramer & 6 & 8 & 14 \\
Satyrinae & Siderone galanthis Cramer & 0 & 3 & 3 \\
& Opsiphanes invirae Huebner & 2 & 3 & 5 \\
& Paryphthimoides phronius Godart & 9 & 10 & 19 \\
& Taygetis thamyra Cramer & 1 & 6 & 7 \\
\hline Total & & 44 & 61 & $\mathbf{1 0 5}$ \\
\hline
\end{tabular}



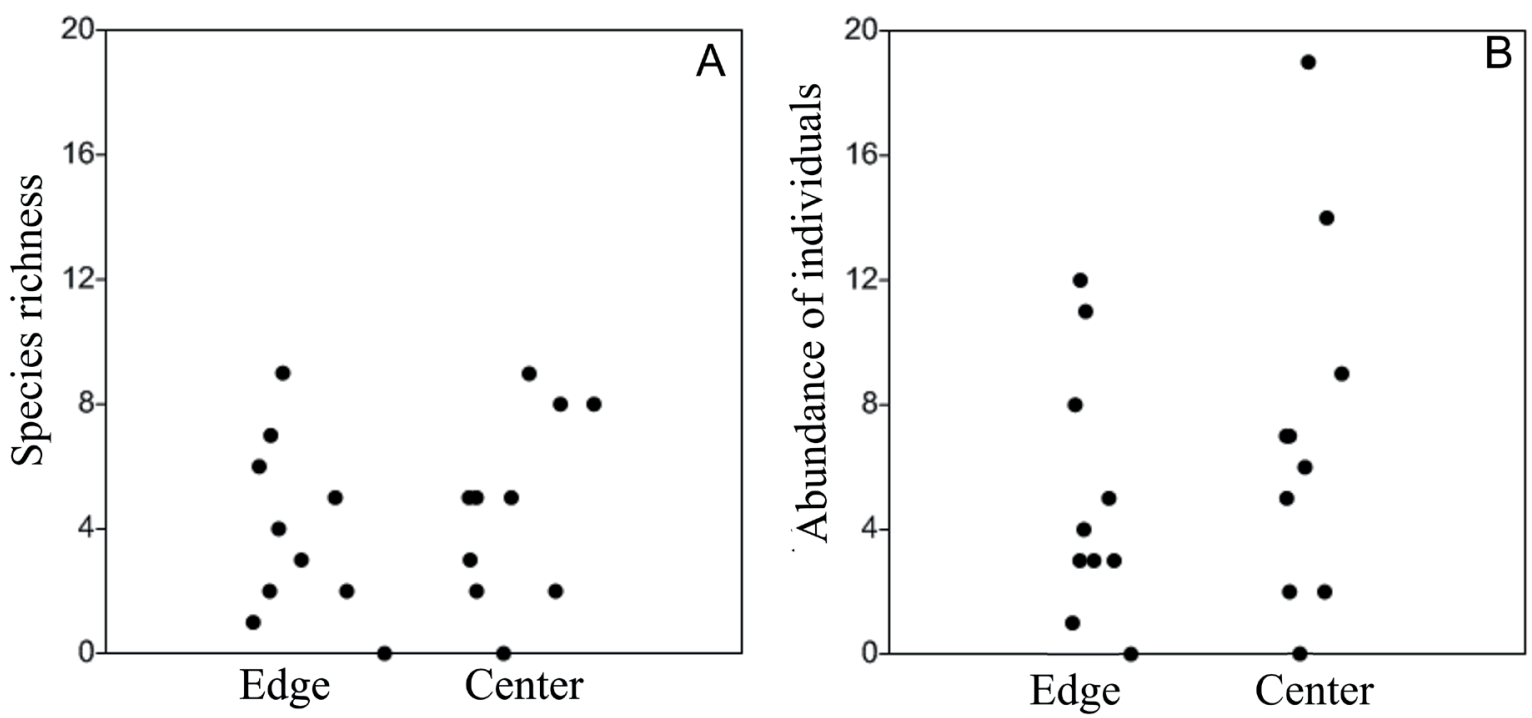

Figure 2. Species richness (A) and Abundance of individuals (B) of butterflies captured at the edge and center of the fragment located at the Universidade Federal de Rondonópolis, MT, from February to May 2019.

of forests and secondary forests, because they prefer to fly in the sun (PAIM 1995; Ramos 2000).

Studies have demonstrated that fragmentation can affect the richness, diversity and composition of the frugivorous butterfly community (e.g. HORNER-DEVINE et al. 2003; SHAHABUDDIN \& PONTE 2005) and the abundance and distribution of populations in relation to their viable size for long-term stay (HANSKI et al. 1996). Highlighting that certain components present in the fragment, such as the degree of isolation and size directly affect the assembly of fruit-feeding butterflies and different biological groups may respond in different ways with respect to fragmentation (CAITANo et al 2020). Furthermore, it should be noted that the characteristics of the vegetation and the permeability of the matrix are factors which are correlated with the distribution of frugivorous butterflies (e.g. Shahabuddin \& Terborgh 1999; Ramos 2000; Uehara-Prado et al. 2005). In general, urbanization has negative effects on species richness and abundance of frugivorous butterfly individuals, often being able to cause local extinctions of certain species more sensitive to drastic changes caused by the conversion of native areas (RAmiReZ-Restepo \& MAcGregor-Fors 2016).

Many groups of insects can assist in the definition of small areas and fragmented habitats with a long history of anthropic influence (Cullen et al. 2003). In this way, the preservation of urban green areas can contribute to the conservation of butterfly fauna. These environments can sustain a high diversity of species, by providing different resources and a less disturbed location in cities, promoting the improvement of the urban ecosystem. (ForTunato \& RUSZCZYK 1997). Distances greater than 150-200 m show distinct community structures of frugivorous butterflies from the edge in fragments of dry forests in the Afrotropical region (BOSSAT \& OPUNI-FRIMPONG 2009). Considering that the average distance from the edges to the central area of the studied fragment is in the range of 150-200 $\mathrm{m}$ we can see that for the locality, the fragment can still be considered as a large edge region, as it is an area in natural regeneration coming from regeneration in the last 30 years since its implantation, being surrounded by urban and pasture areas. In this way, we see that because it is a small Cerrado area, fauna regeneration processes can be more sensitive and time consuming because it does not guarantee the minimum functionality of the ecosystem to ensure the presence of species considered typical of preserved/ conserved areas.

Therefore, it is concluded that the urbanization process directly influences the number and presence of butterfly species, highlighting the potential that they have as biological

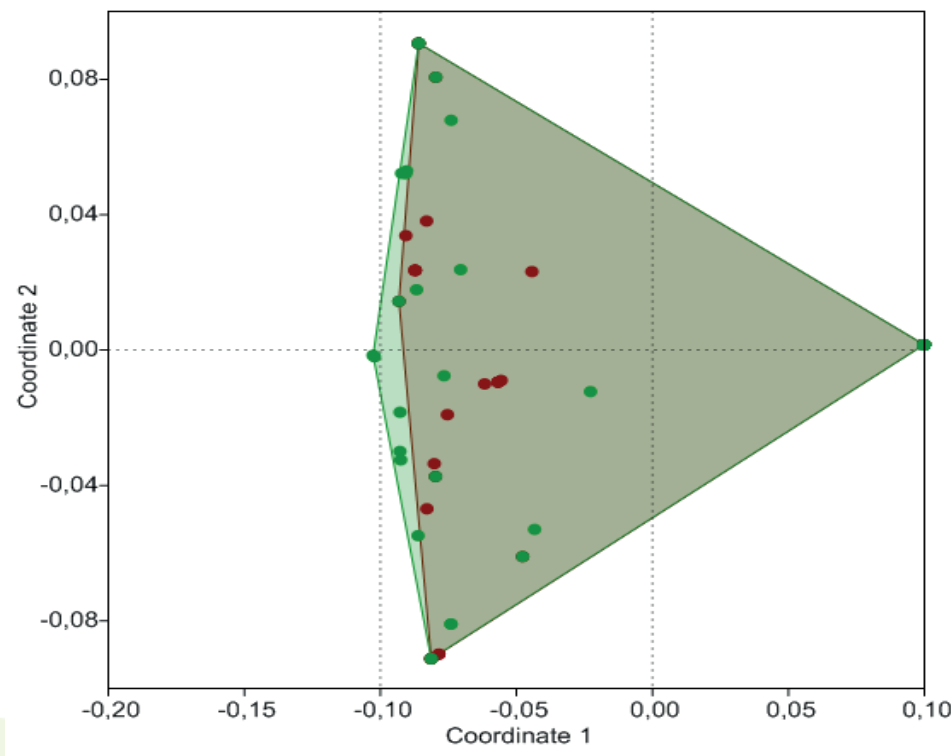

Figure 3. Non-metric multidimensional scaling (NMDS) of the composition of frugivorous butterflies in the center and at the edge of the fragment in the period from February to May 2019, red dots= edger, green dots= center of the fragment. 
Table 2. Percentage of similarity with individual and cumulative importance of each species between edge and center, indicating which species were more important in the similarity between areas.

\begin{tabular}{lcc}
\hline Táxon & Contribution \% & \% Acumulative \\
\hline Hamadryas feronia Linnaeus & 22,79 & 22,79 \\
\hline Hamadryas februa Hubner & 17,58 & 40,38 \\
\hline Paryphthimoides phronius Godart & 16,68 & 57,05 \\
Temenis laothoe Ebert & 11,85 & 68,9 \\
\hline Callicore sorana Godart & 8,55 & 77,45 \\
Taygetis thamyra Cramer & 7,68 & 85,13 \\
Nica flavilla Godart & 5,73 & 90,86 \\
Opsiphanes invirae Huebner & 4,90 & 95,79 \\
\hline Siderone galanthis Hubner & 4,24 & 100 \\
\hline
\end{tabular}

indicators in the study area. It is worth mentioning that due to the fragment, it is still in a state of regeneration and has been impacted by anthropic activities. We must continue with efficient tools in the process of diagnosis and environmental monitoring the area, thus contributing to the adoption of mitigating actions and measures responsible for ensuring the maintenance of habitat and local biodiversity.

\section{REFERENCES}

Alho, CJR \& ES Martins, 1995. De Grão em Grão, o Cerrado Perde Espaço: Cerrado - Impactos do Processo de Ocupação. Brasília.

Bossart, JL \& E Opuni-Frimpong, 2009. Distance from edge determines fruit-feeding butterfly community diversity in Afrotropical forest fragments. Environmental Entomology, 38: 43-52. DOI: https://doi.org/10.1603/022.038.0107

Brow Jr, KS, 1992. Borboletas da Serra do Japi: diversidade, habitats, recursos alimentares e variação temporal. pp. 142-186. In: Morellato, LPC (Eds.). História Natural da Serra do Japi: ecologia e preservação de uma área florestal no Sudeste do Brasil. Campinas, São Paulo, Editora UNICAMP/ FAPESP.

Brown, KS \& AVL Freitas, 1999. Lepidoptera, pp. 227-243. In: Brandão, CRF, \& EM Cancello (Eds.). Biodiversidade do Estado de São Paulo, Brasil: síntese do conhecimento ao final do século XX. São Paulo: FAPESP.

Brown, KS, 1996. Diversity of Brazilian Lepidoptera: history of study, methods for measurements, and use as indicator for genetic, specific and system richness, pp. 221-253. In: Bicudo, CEM \& NA Menezes (Eds.). Biodiversity in Brazil: a first approach. Instituto de Botânica, CNPq, São Paulo.

Brown Jr, KS \& AVL Freitas, 2002. Butterfly communities of urban forest fragments in Campinas, São Paulo, Brazil: structure, instability, environmental correlates, and conservation. Journal of Insect Conservation, 6: 195-206.

Bogiani, PA, R Aranda \& CDOF Machado, 2012. Riqueza de borboletas (Lepidoptera) em um fragmento urbano de Cerrado em Mato Grosso do Sul, Brasil, EntomoBrasilis, 5: 93-98. DOI: https://doi.org/10.12741/ebrasilis.v5i2.204

Caitano, B, TP Chaves, P Dodonov \& JHC Delabie, 2020. Edge effects on insects depend on life history traits: a global meta-analysis. Journal of Insect Conservation, 24: 233-240. DOI: https://doi.org/10.1007/s10841-020-00227-1

Capinera, J.L. 2008. Butterflies and moths, pp. 626-672. In: Capinera, J.L. (Eds.) Encyclopedia of entomology, Springer Science \& Business Media.

Cullen, L, C Padua-Valadare \& R Rudran, 2003. Métodos de estudos em biologia da conservação e manejo da vida silvestre. Curitiba: Editora UFPR.

De Campos, EP, GL Silveira, CAS Dalla \& NLA da Silva, 2018. Florística e hábitos das espécies vegetais de um fragmento de cerrado em Rondonópolis, MT. Biodiversidade, 17: 16-
27.

Dessuy, MB \& A Morais, 2007. Diversidade de borboletas (Lepidóptera, Papilionoidea e Hesperioidea) em fragmentos de floresta estacional decidual em Santa Maria, Rio Grande do Sul, Brasil. Revista Brasileira de Zoologia, 24: 108- 120. DOI: https://doi.org/10.1590/ s0101-81752007000100014

DeVries, PJ, D Murray \& R Lande, 1997. Species diversity in vertical, horizontal, and temporal dimensions of a fruitfeeding butterfly community in an Ecuadorian rainforest. Biological Journal Linnean of Society, 62: 343-364. DOI: https://doi.org/10.1111/j.1095-8312.1997.tb01630.x

DeVries, PJ, 1987. The butterflies of Costa Rica and their natural history: Papilionidae, Pieridae, amd Nymphalidae. Princeton, Princeton University Press.

DeVries, PJ \& TR Walla, 2001. Species diversity and community structure in neotropical fruit-feeding butterflies. Biological Journal of Linnean Society, 74: 1-15. DOI: https://doi.org/10.1111/j.1095-8312.2001.tb01372.x

Fahrig, L, 2003. Effects of HabitatFragmentation on Biodiversity. Annual Review of Ecology and Systematics, 34: 487-515. DOI: https://doi.org/10.3724/sp.j.1003.2011.07036

Feiden, A, DD Castagnara, A Uhlein, M Kipper, NLS Silva \& WJ Zonin, 2008. Quantificação dos Fragmentos Florestais Existentes na Microbacia Hidrográfica da Sanga Mineira - Município de Mercedes - PR. Revista Brasileira de Biociencias, 6: 29-31.

Felfili, JM. \& MC Silva Júnior, 2001. Biogeografia do Bioma Cerrado: estudo fitofisionômico da Chapada do Espigão Mestre do São Francisco, Editora UNB.

Freitas, AVL, RB Francini \& KS Brown Jr, 2003. Insetos como indicadores ambientais, pp.125-151. In: Cullen, Jr L, R Rudran \& C Valladares-Padua (Eds.) Métodos de estudos em biologia e manejo da vida silvestre, Editora da UFPR, Curitiba.

Freitas, AVL, CA Iserhard, JP Santos, JYO Oliveira, DR Bandini, DHA Melo, AHB Rosa, OJ Marini-filho, GM Accacio \& M Uehara-Prado, 2014. Studies with butterfly bait traps: an overview. Revista Colombiana de Entomología, 40, 203212.

Fortunato, L \& A Ruszczyk, 1997. Comunidades de Lepidópteros frugívoros em áreas verdes urbanas e extraurbanas de Uberlândia, MG. Revista Brasileira de Biologia, 57: 79-87.

Gomes Filho, A, 2003. A comunidade de borboletas frugívoras da Reserva de Santa Genebra, Campinas, SP, com enfase na flutuação populacional de Anaea ryphea (Cramer) (Nymphalidae: Charaxinae) e sua relação com as plantas hospedeiras. Thesis (PhD in Ecology) Instituto de Biologia, Universidade Estadual de Campinas, Campinas, SP.

Hamer, KC, JK Hill, N Mustaffa, S Benedick, TN Sherratt, VK Chey \& M Maryati, 2005. Temporal variation in abundance and diversity of butterflies in Bornean rain 
forest: opposite impacts of logging recorded in different seasons. Journal of Tropical Ecology, 21: 417-425. DOI: https://doi.org/10.1017/s0266467405002361

Hanski, I, A Moilanen \& M Gyllenberg, 1996. Minimum viable metapopulation size. American Naturalist, 147: 527-541. DOI: https://doi.org/10.1086/285864

Heppner, JB, 1991. Faunal regions and the diversity of Lepidoptera. Tropical Lepidoptera, 2: 1- 85.

Hogue, CL, 1993. Latin American: insects and entomology. Berkeley, University of California Press.

Horner-Devine, MC, GC Daily, PR Ehrlich \& CL Boggs, 2003. Countryside biogeography of tropical butterflies. Conservation Biology, 17: 168-177. DOI: https://doi. org/10.1046/j.1523-1739.2003.01310.x

IBGE, 2018. Cidades, Instituto Brasileiro de Geografia e Estatística. Available in: <https://cidades.ibge.gov.br/>

Junior, BFG, 2015. Dinâmica temporal e espacial da comunidade de borboletas frugívoras (Nymphalidae) do Cerrado. Thesis (PhD in Ecology) - Universidade Federal de Brasília, Brasília.

Mckinney, ML \& JL Lockwood, 1999. Biotic homogenization: a few winners replacing many losers in the next mass extinction. Trends in Ecology \& Evolution, 14: 450-453. DOI: https://doi.org/10.1016/s0169-5347(99)01679-1

New, TR, RM Pyle, JA Thomas \& PC Hammond, 1995. Butterfly conservation management. Annual Review of Entomology, 40: 557-883. DOI: https://doi.org/10.1146/annurev. en.40.010195.000421

Paim, AC, 1995. Polimorfismo enzimático e variação morfológica em uma população natural de Dryas iulia (Fabr. 1775) (Lepidoptera; Nymphalidae). Dissertation (Master: Programa de Pós-Graduação em Genética e Biologia Molecular, Universidade Federal do Rio Grande do Sul. Instituto de Biociências.

Ramírez-Restrepo, L \& I MacGregor-Fors, 2017. Butterflies in the city: a review of urban diurnal Lepidoptera. Urban ecosystems, 20: 171-182. DOI: https://doi.org/10.1007/ s11252-016-0579-4

Ramos, FA, 2000. Nymphalid butterfly communities in an Amazonian forest fragment. Journal of Research on the Lepidoptera, 35: 29-41.

Ribeiro, DB, R Batista, PI Prado, KS Brown Jr \& AV Freitas, 2012. The importance of small scales to the fruit-freeding butterfly assemblages fragmented landscape. Biodiversity Conservation, 21: 811-827. DOI: https://doi.org/10.1007/ s10531-011-0222-x

Santos, JP, AVL Freitas, PAL Constantino \& M Uehara-Prado, 2014. Guia de identificação de tribos de borboletas frugívoras - Cerrado. Monitoramento de Biodiversidade. MMA/ICMBio/GIZ. Brasília. Brazil.

Santos, JP, OJ Marini-Filho, AVL Freitas \& M Uehara-Prado, 2016. Monitoramento de borboletas: o papel de um indicador biológico na gestão de unidades de conservação. Biodiversidade Brasileira, 6: 87-99.
Schmidt, DG, LD Costa, A Elpino-Campos \& EA Barp, 2012. Diversidade de borboletas (Lepidoptera) na borda e no interior de um fragmento de mata no município de Seara, SC. Saúde e Meio Ambiente, 1: 3-15. DOI: https://doi.org/10.24302/sma.v1i2.263

Sette, DM, 1996. O clima urbano de Rondonópolis - MT. Dissertation (Master: Programa de Pós-graduação em Geografia Física) Faculdade de Filosofia Letras e Ciências Humanas. Universidade de São Paulo, São Paulo.

Sette, DM \& JR Tarifa, 2001. Clima e Ambiente urbano tropical: o caso de Rondonópolis-MT. Intergeo, 1: 26-35.

Shahabuddin, G \& CA Ponte, 2005. Frugivorous butterfly species in tropical forest fragments: correlates of vulnerability to extinction. Biodiversity and Conservation, 14: 1137-1152. DOI: https://doi.org/10.1007/s10531-0047842-3

Shahabuddin, G \& JW Terborgh, 1996. Frugivorous butterflies in Venezuelen forest fragments: abundanc, diversity, and the Effects of isolation. Journal of Tropical Ecology, 15: 703722. DOI: https://doi.org/10.1017/s0266467499001121

Silva, ARM, COD Castro, PO Mafia, MOC Mendonça, TCC Alves \& MDV Beirão, 2012. Borboletas frugívoras (Lepidoptera: Nymphalidae) de uma área urbana (Área de Proteção Especial Manancial Cercadinho) em Belo Horizonte, Minas Gerais, Brasil. Biota Neotropica, 12: 292-297. DOI: https://doi.org/10.1590/s1676-06032012000300028

Silva, ARM, GG Landa \& RF Vitalino, 2007. Borboletas (Lepidoptera) de um fragmento de mata urbano em Minas Gerais, Brasil. Lundiana, 8: 137-142. DOI: https://doi.org/10.1590/s1676-06032012000400022

Sousa, WOD, LE Sousa, FR da Silva, WI Santos \& R Aranda, 2019. Composition and structure of the frugivorous butterfly community (Lepidoptera: Nymphalidae) at the Serra Azul State Park (PESA), Mato Grosso, Brazil. Zoologia, 36: e27708. DOI: https://doi.org/10.3897/zoologia.36. e27708

Uehara-Prado, M, KS Brown Jr. \& AVL Freitas, 2005. Biological traits of frugivorous butterflies in a fragmented and a continuous landscape in the South Brazilian Atlantic Forest. Journal of the Lepidopterists' Society, 59: 96-106.

Uehara-Prado, M, KS Brown Jr \& AVL Freitas, 2007. Species richness, composition and abundance of fruit-feeding butterflies in the Brazilian Atlantic Forest: comparison between a fragmented and a continuous landscape. Global Ecology and Biogeograph, 16: 43-54. DOI: https://doi.org/10.1111/j.1466-822x.2006.00267.x

Uehara-Prado, M, AVL Freitas, RB Francini \& KS Brown $J r$, 2004. Guia das borboletas frugívoras da Reserva Estadual do Morro Grande e região de Caucaia do Alto, Cotia (São Paulo). Biota Neotropica, 4: 1-25. DOI: https://doi.org/10.1590/s1676-06032004000100007

\section{Suggestion citation:}

Porath, IAT \& R Aranda, 2020. Frugivorous butterflies (Lepidoptera: Nymphalidae) as a habitat quality indicator in Cerrado urban fragment. EntomoBrasilis, 13: e904.

Available in: doi: 10.12741/ebrasilis.v13.e904
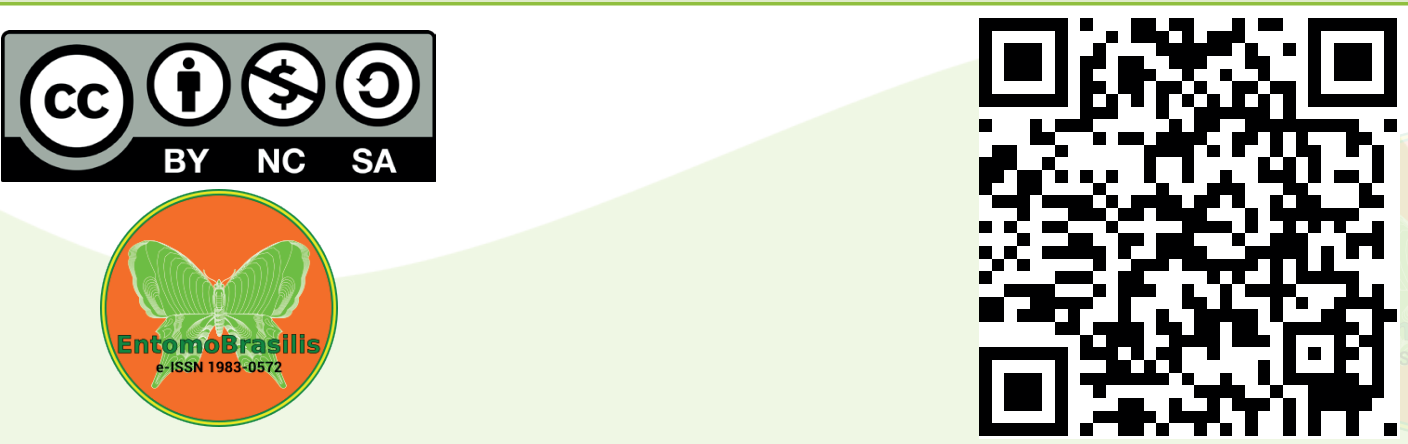